\title{
Geospatial Modeling of Landslide Vulnerability and Simulating Spatial Correlation with Associated Factors in Bandarban District
}

\author{
Md. Sofi Ullah \\ Department of Geography and Environment, University of Dhaka, Dhaka 1000, Bangladesh \\ Manuscript received: 22 August 2020: accepted for publication: 5 January 2021
}

\begin{abstract}
The present study aims at identifying and predicting landslide vulnerable areas in Bandarban District of Chittagong Hill Tracts (CHT) using weighted overlaying of the multiple geospatial layers to determine landslide hazard areas. The historical landslide inventory map was prepared using Google Earth image and through PRA technique. Then ten landslide triggering factors including landuse, rainfall, slope, elevation, cut-fill, soil types, geology, distance to rivers, roads and stream orders, population density, income, education of the inhabitants were chosen as effective factors on a landslide in the study area. Subsequently, the landslide vulnerability map was constructed using the weighted overlay model in Geographic Information System (GIS). Bandarban District has 348 landslides vulnerable locations. Among them, 6 are extremely vulnerable and 342 are highly vulnerable to landslides. Model results show that the Upazila Ruma and Thanchi are extremely vulnerable to landslides. About 91 percent of the landslides will occur within 10 degrees of slope, about 65 percent will occur within 50 meters elevation. The model shows that there is a strong relationship between landslides and physical, economic and social variables.
\end{abstract}

Keywords: Landslides vulnerability, Simulating, Spatial correlation, Weighed overlay, ArcGIS model builder

\section{INTRODUCTION}

Landslide is the process of displacement of soil and rocks on slopes and one of the most common natural hazards in many mountainous areas and greatly affect the social sustainability of human beings (Formetta et al., 2014; Lee et al., 2017; Jeong et al., 2017; Cruden and Varnes, 1996). There are natural and man-made causes of landslides. The natural causes, such as elevation, slope, soil types, geology, heavy rainfall, and earthquakes, but the man-made causes are deforestation, land altering, cutting, urban encroachments, etc. Significant studies have focused rainfall-induced landslides in last few decades to explore the effective measures to enhance public safety (Safaei et al., 2011; Crosta and Frattini, 2008).

As a consequence, several landslide risk modeling applications have been developed, such as GEOtop (Simoni et al., 2008) and SHETRAN (El-Emam and Bathurst, 2007), which can calculate risk over large areas using hydrological and mechanical elements. Other applications can evaluate landslide hazards for smaller areas such as catchments of a few square kilometers (Dietrich and Montgomery, 1988; Dhakal and Sidle, 2003).

Corresponding author: Md. Sofi Ullah

E-mail: sofiullah.geoenv@du.ac.bd

DOI: https://doi.org/10.3329/dujees.v8i2.54839
Landslides are very important hazards around the world, and they are often connected with other hazards such as volcanic activity or earthquakes (Keller and Blodgett, 2004). The occurrence of the most landslides are small in size and slow but some landslides are faster and bigger with catastrophic consequences. All kinds of landslides are often correlated with geological materials of the earth surface (Korup, 2004, 2005, 2006). Therefore, the composition and consolidation of the materials are very important factors in the stability of the soil mass and rocks (Mitchell et al., 2002).

There are five types of movement in landslides (Turner and Schuster, 1996); fall, topple, slide, spread and flow.

a) Fall is a vertical movement extremely or very rapid and can be as rocks or debris. This type has low moisture (Summerfield, 1991).

b) Topple is a rotation out of a mass of soil or rock about a point or axis below the centre of gravity of the displaced mass.

c) The slide is a downslope movement of soil or rock mass where there is a rupture of the surface. There are two types of slides, rotational or translational and the moisture is low or moderate (Summerfield, 1991).

d) Spread is a movement of cohesive soil or rock mass over a material unstable. The moisture is moderate to high and this movement is very 
complex due to the different materials and the water interaction.

e) Finally, Flow is a movement of no consolidate materials and this movement can be fast or slow depends on the materials and the moisture (Summerfield, 1991).

Studies show that there are five factors in the landslides (Keller and Blodgett, 2004); materials, slope, climate, weather, vegetation, and water. These factors may act together or separately and they have different consequences in the landslides. The inclination of the slope is important as well because in general, when the slope is higher the driving force is also higher. If there is a high slope, fall is the more usual type and when the slope is low, flows are the most frequent. Climate is different around the world and mainly it has an important role in superficial landslides. In arid climates where vegetation is sparse, landslides are frequent like fall, debris flow, and superficial landslides because soil mass and rocks are exposed to high erosion. However, humid and sub-humid areas have abundant vegetation and soil mass cover most of the slopes and the landslides are more complex (Hildenbrand et al., 2003). Weather can be a complex problem in different types of landslides. Extreme weather events such as the high intensity of rainfall or long periods of rain may produce dangerous landslides.

Assessing and mapping landslide susceptibility is an established practice, often aimed at comparing different predictive methods, which offers the possibility for a dynamic, integrated and on-going management of the territory and its sudden modifications (Devkota et al., 2013; Kavzoglu et al., 2014; Pellicani et al., 2014; Shahabi et al., 2014; Pham et al., 2016). On the contrary, quantifying, in mathematical terms, the landslide risk can be very complicated, due to several aspects related to the complexity in assessing the temporal probability of a specific landslide event with given intensity (hazard) and the probability of damaging a given element at risk, i.e. vulnerability (Glade 2003; Uzielli et al., 2008; Pellicani et al., 2014; Abdulwahid and Pradhan, 2016).

The risk assessment in probabilistic terms requires the analysis of (1) the probability of occurrence of a rock fall event with a given magnitude, depending on the rock fall frequency- magnitude relationship and triggering event frequencies, (2) the probability that a boulder reaches the element at risk depending on the propagation process along the slope and mobility of element at risk, (3) vulnerability which depends on rock fall intensity and characteristics of exposed assets and (4) economic value of elements at risk, in terms of damaging of road and vehicles, interruption of traffic and loss of life (Corominas et al., 2005; Agliardi et al., 2009; Mavrouli and Corominas, 2010; Ferlisi et al., 2012; Wang et al., 2014).

In Bangladesh, level of precipitation is in increasing trend, while temperature has increased $1^{\circ} \mathrm{C}$ or less in the last fifty years (Sofiullah, 2018). Increase of pre-monsoon (7-8 percent) and monsoon rains (5-7 percent) is also remarkable (Sofiullah et al. 2017), which could have led to a significant rise in landslide incidence in the country in recent past (Figure 1). Furthermore, landslide risk period might be prolonged due to increasing pre-monsoon precipitation followed by heavy monsoon downpour and eventually would lead to a significant incidence of landslides.

Landslides occur almost every year; however, the scope and scale of 2007, 2010, and 2017 were some of the worst. The landslides of June 2007 killed 135 people and affected 1.5 million people when heavy monsoon rainfall intensified by a strong storm from the Bay of Bengal caused abnormal precipitation in the landslide area (BBS, 2011). During the landslides of June 2017 , it was reported that 80,000 people were affected across all five districts of Chattogram Division. However, among these, 42,000 were considered severely impacted because their homes had been destroyed. The most affected districts were Chattogram, Rangamati and Bandarban. Though the number of people severely affected is quite large, there is a clear decrease in the affected population since 2007 (Table 1). This can be attributed to the resilience planning being done to address landslide risks.

Table 1: Landslide Affected Population

\begin{tabular}{|l|l|l|l|}
\hline $\begin{array}{l}\text { Disaster and its } \\
\text { Associate }\end{array}$ & $\begin{array}{l}\text { June, } \\
2017\end{array}$ & $\begin{array}{l}\text { June, } \\
2010\end{array}$ & $\begin{array}{l}\text { June, } \\
2007\end{array}$ \\
\hline $\begin{array}{l}\text { Severely affected } \\
\text { population }\end{array}$ & 42,000 & 13,900 & $1,500,000$ \\
\hline \multicolumn{2}{|c|}{ Source: BBS, 2011}
\end{tabular}

Numerous studies were conducted for modeling and mapping landslide susceptibility based on the analysis of the relationships among the existing 
historical landslides data and various factors predisposing instability as well as weighted according to their influence on the instability process (Soeters and Van Westen, 1996; Van Westen, 2000; Ayalew et al. 2005; Fell et al. 2008).

To perform a landslide susceptibility prediction model, GIS and Remote Sensing are the tools of paramount importance since it allows, because of their computational power, to manage data with a high degree of spatial variability (Van Westen, 2000). Therefore, GIS and Remote Sensing offer the possibility for a dynamic, integrated and on-going management of the territory and its sudden modifications.

Landslide is one of the most devastating hazards in the hilly areas and has increased in recent years. The effect of landslide can be significantly reduced by developing landslide probability model for the study area. However, the literature does not identify any such model for the study area even for the country.

The geospatial modeling on landslide vulnerability locations and establishing multivariate relationships will eventually help to meet the objective of poverty reduction of the local community at the micro-level. It is expected that the present study will facilitate in achieving the sustainable development goals (SDGs), and hope to meet the research gaps in the country. Therefore, the present study will be a milestone in the research fields.

\section{THE OBJECTIVE OF THE STUDY}

The study aims at modeling landslides vulnerability in Bandarban District of Chittagong Hill Tracts (CHT). The specific objectives are the following:

- to predict landslide vulnerable locations

- to simulate physical indicators correlated to the landslides

- to simulate social indicators correlated to the landslides

- to simulate economic indicators correlated to the landslides

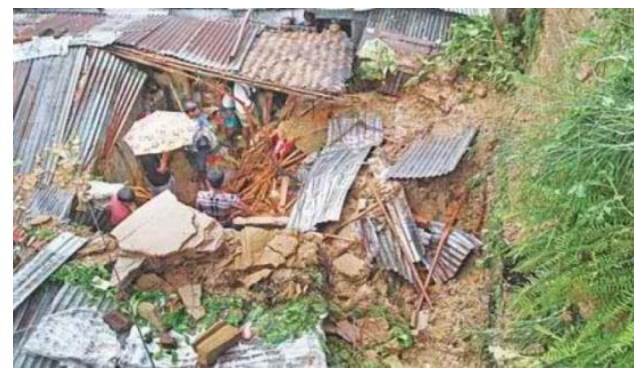

(1)

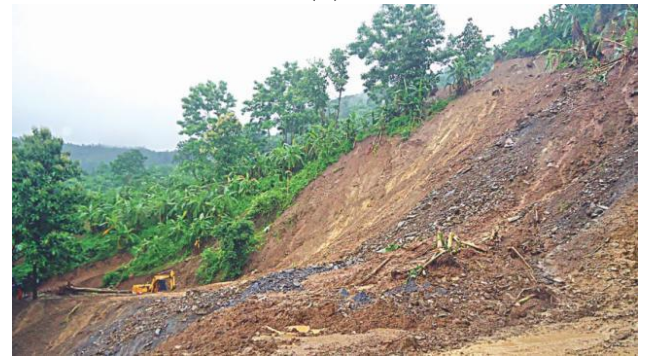

(2)

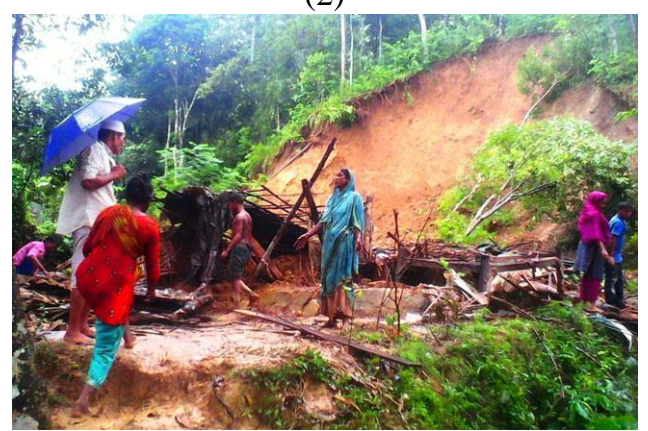

(3)



(4)



(5) 


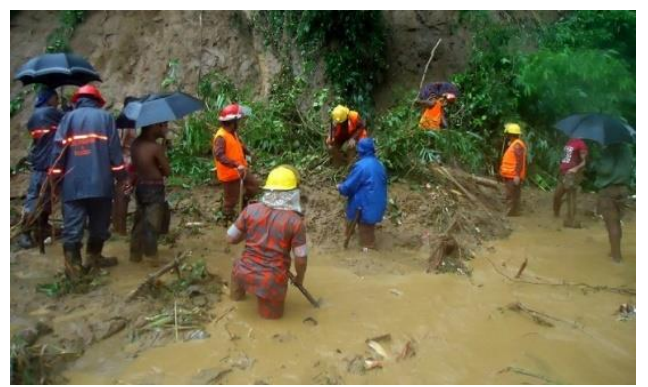

(6)

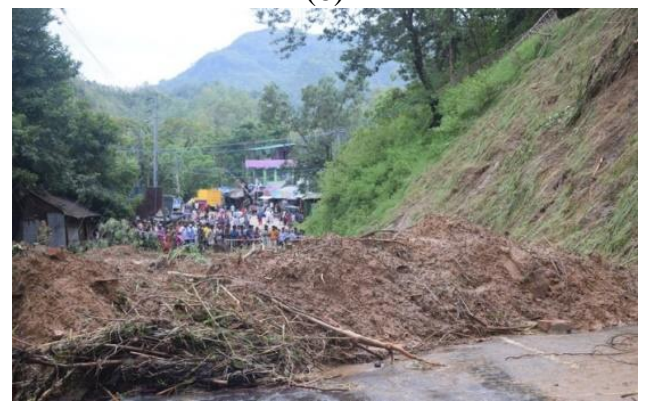

(7)

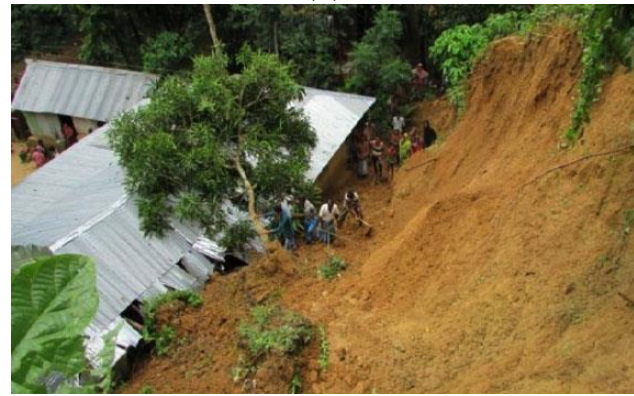

(8)

Figure 1: Landslide Scenarios in Bandarban and Rangamati District, Bangaldesh (01) Landslide at Dalianpara of Ruma Upazila in Bandarban. New Age Bangladesh: Jul 28, 2017; (02) Landslide in Dolian Para of Bandarban. Photo: Sanjoy Kumar Barua: Daily Star: 24 July 2017; (03) Landslide in Ruma, Bandarban, Daily Ittefaq, 23rd July 2017; (04) Landslide in Bandarban, Bandarban-Ruma Road was Blocked, bdnews24.com; (05) Rangamati Landslide, Dhaka Tribune, 13 June 2017; (06) Rescue Workers Search for Bodies After a Landslide in Bandarban, Associated Press via AFP June 13, 2017, (07) Devastates Several Households in Rangamati District Dhaka Tribune, June 13, 2017; (08) Four People were Killed by Landslide in Bandarban: Daily Ittefaq, 3 July 2018.

\section{STUDY AREA}

The study area Bandarban, one of the three hill districts of Bangladesh and a part of the Chittagong Hill Tracts (CHT). It lies between $21^{\circ} 11^{\prime \prime}$ and $22^{\circ} 22^{\prime \prime}$ north latitudes and $92^{\circ} 04^{\prime \prime}$ and $92^{\circ} 41^{\prime \prime}$ east longitudes. It has 7 Upazilas, among them the present study considered 5 Upazilas for the study, and these are Bandarban Sadar, Lama, Rowangchhari, Ruma and Thanchi Upazila (Figure 2). Furthermore, the study area has 24 unions, 1670 villages, 2 Paurashavas and 1579 mahallas According to BBS, the total study area is about $3129.6 \mathrm{~km}^{2}$, among them $1244.78 \mathrm{~km}^{2}$ (39.77 percent of the total land) is land area, 1881.66 $\mathrm{km}^{2}$ is reserve forest area, and only $3.16 \mathrm{~km}^{2}$ is riverine area (BBS, 2011).

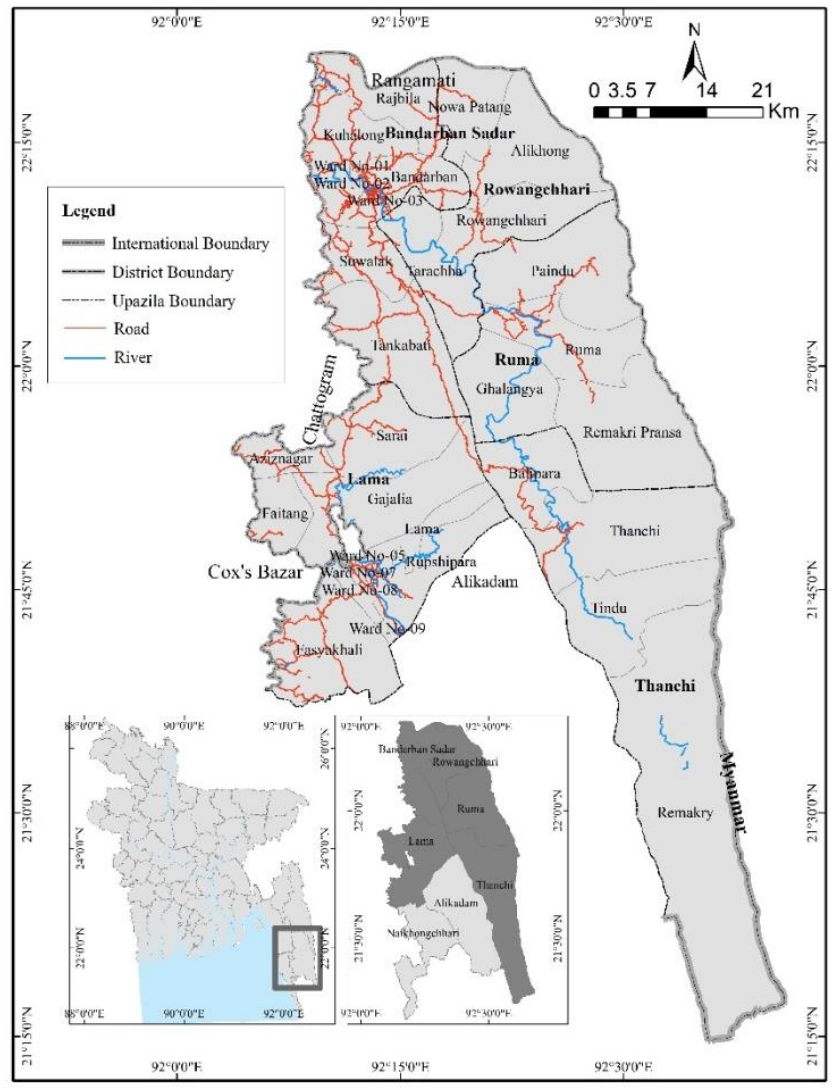

Figure 2: Location of the Study Area

\section{MATERIALS AND METHOD}

\section{Materials}

Both primary and secondary data were used in the present study. Secondary data such as 1: 25000 scale topographic data were collected from Survey of Bangladesh (SoB). Last fifty years rainfall data were collected from Bangladesh Meteorological Department (BMD). Soil type data were collected from Soil Research Development Institute (SRDI). Soil compactness and geological formation data were collected from Geological Survey of Bangladesh (GSB). Different boundary data of the study area were collected from Bangladesh Bureau of Statistics (BBS). Household census such as household locations, 
household income, education, tribal, non-tribal data were collected from HKI (Helen Keller International). Digital Elevation Model (DEM) data were collected from Shuttle Radar Topography Mission (SRTM) and Advanced Space borne Thermal Emission and Reflection (Aster) platforms. Besides, all kind of satellite data were collected from Landsat 4-5 TM and Landsat $8 \mathrm{oli} /$ tirs sensors. High resolution 0.4 meter satellite images for the study area were collected from Google Earth platform. The following datasets were considered in the study (Table 2).

Table 2: Indicators of the Landslides Vulnerability

\begin{tabular}{|l|l|}
\hline Indicators & Data Sources \\
\hline $\begin{array}{l}\text { Historical } \\
\text { Inventory }\end{array}$ & $\begin{array}{l}\text { PRA through using 0.4 meters } \\
\text { Google Images }\end{array}$ \\
\hline Elevation & SRTM DEM \\
\hline Slope & SRTM DEM \\
\hline Geology & Geological Survey of Bangladesh \\
\hline Soil types & Soil Resource Development Institute \\
\hline Streams & SRTM DEM Data \\
\hline Rivers & $\begin{array}{l}\text { Survey of Bangladesh (SoB), 1: } \\
\text { 25000 Scale Topographic Dataset }\end{array}$ \\
\hline Roads & $\begin{array}{l}\text { Survey of Bangladesh (SoB), 1: } \\
\text { 25000 Scale Topographic Dataset }\end{array}$ \\
\hline Land use & $\begin{array}{l}\text { Survey of Bangladesh (SoB) and } \\
\text { Landsat Satellite Images }\end{array}$ \\
\hline Cut and Fill & SRTM DEM and ASTER DEM \\
\hline Rainfall & $\begin{array}{l}\text { Bangladesh } \\
\text { Department (BMD) }\end{array}$ \\
\hline Population density & Household Census Data by HKI \\
\hline Education & Household Census Data by HKI \\
\hline Income & Household Census Data by HKI \\
\hline Landuse & $\begin{array}{l}\text { Survey of Bangladesh and Landsat } \\
\text { Images }\end{array}$ \\
\hline
\end{tabular}

\section{Method}

The method followed in this study is described in detail in the following sections.

Landslide inventory: Historical landslide inventory were completed using field level PRA (Participatory Rural Appraisal) techniques. A total 17 PRA were conducted in 17 unions. Each PRA was represented by all stockholders of the community (Figure 3).


Figure: 3: Conducting PRA Representing by the Local Peoples (Photograph Curtesy by Anamik Ani Khan, HKI)

Analysis of triggering events. An analysis of triggering events was carried out in order to be able to correlate landslide inventories of particular triggering events like slope in degree, elevation, stream, river, roads and landuse, rainfall, geology, soil types etc. From the available data, the landslide triggering events were identified (Figure 4).

A Digital Elevation Model (DEM) was used for generating derivative maps, such as elevation classes, slope steepness, slope direction and flow accumulation. Roads, stream and rivers were used to generate distance maps to evaluate the effect of landslide occurrence close to these features. Besides exiting geology, and soil types were used to assess the landslides vulnerability (Figure 4). 




Figure 4: Workflow of Landslide Vulnerability Modeling
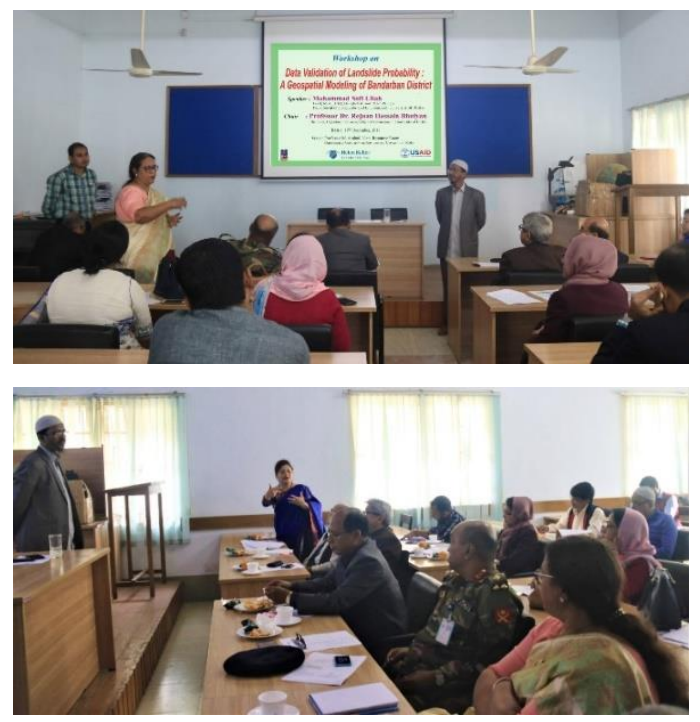

Figure 5: Landslide Modeling Data Validation Workshop Representing Expert of the Various Sectors

Bivariate statistical analysis. All data and investigation processes were validated through a workshop representing all related stakeholders (Figure
5). ArcGIS Model Builder model was used to identify landslides vulnerability in Bandarban. All datasets were weighted overlaid in a scale of 1 to 10 by 1 with 100 influence level (Appendix 1) where each influence was set according to the layer importance in the landslides respect (Figure 6).

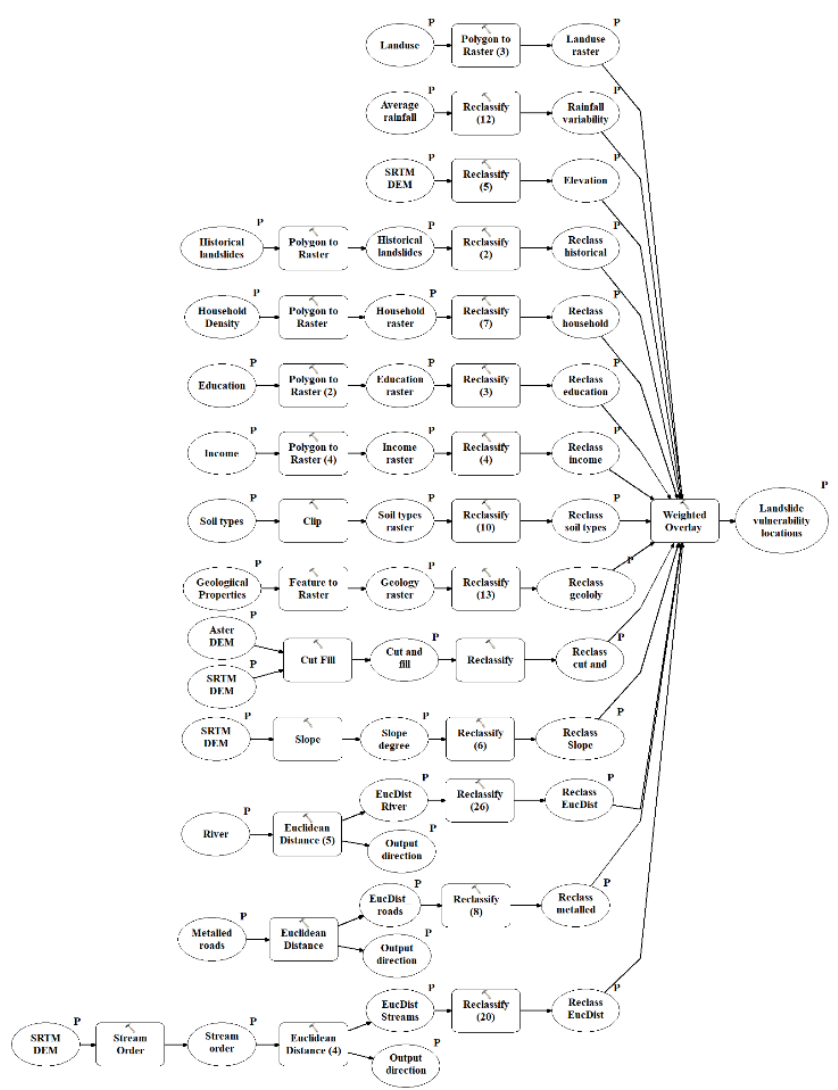

Figure 6: Geospatial Landslide Vulnerability Model in ArcGIS Model Builder

\section{RESULTS AND DISCUSSIONS}

Model shows that, there are a total of six locations, those are extremely vulnerable to landslides in Bandarban District. The areal extend of the extreme landslide vulnerability is 37.45 hectares. Data shows that a total $44,434 \mathrm{sq}$ meters area in Remakri Pransa union of Ruma Upazila, 13,3304 sq meters in Thanchi union of Thanchi Upazila and 196,746 sq meters in Tindu union of Thanchi Upazila area extremely vulnerable to the landslides (Table 2). There is one location in Remarkri Pransa union of Ruma Upazila, 3 in Thanchi union of Thanchi Upazila and 2 in Tindu union of Thanchi Upazila are extremely vulnerable to landslides (Figure 7). 
Table 2: Extremely Vulnerable Landslide Locations in Bandarban District

\begin{tabular}{|l|l|l|l|}
\hline $\begin{array}{l}\text { Upazila } \\
\text { name }\end{array}$ & Union name & $\begin{array}{l}\text { No. of } \\
\text { Locations }\end{array}$ & $\begin{array}{l}\text { Landslide vulnerable } \\
\text { area (sq meter) }\end{array}$ \\
\hline Ruma & Remakri Pransa & 1 & 44434.93 \\
\hline \multirow{2}{*}{ Thanchi } & Thanchi & 3 & 133304.79 \\
\cline { 2 - 4 } & Tindu & 2 & 196746.33 \\
\hline Total & 06 & 37.45 (HA) \\
\hline \multicolumn{4}{|c|}{ Source: Data simulation using geospatial model, 2018 }
\end{tabular}

Table 3: Highly Vulnerable Landslide Locations in Bandarban District

\begin{tabular}{|l|l|l|l|l|}
\hline $\begin{array}{l}\text { Name of } \\
\text { the } \\
\text { Upazila }\end{array}$ & $\begin{array}{l}\text { Total area } \\
\text { (in } \\
\text { hectares) }\end{array}$ & $\begin{array}{l}\text { High } \\
\text { vulnerable area } \\
\text { (in hectares) }\end{array}$ & $\begin{array}{l}\text { No. of } \\
\text { locations } \\
\text { vulnerable }\end{array}$ & $\begin{array}{l}\text { Percent of } \\
\text { vulnerable } \\
\text { (based on } \\
\text { total area) }\end{array}$ \\
\hline Thanchi & 98564.93 & 2031.37 & 69 & 0.62 \\
\hline Lama & 70335.85 & 9274.43 & 119 & 2.83 \\
\hline Ruma & 62740.62 & 517.88 & 36 & 0.16 \\
\hline $\begin{array}{l}\text { Rowangch } \\
\text { hari }\end{array}$ & 43608.71 & 1063.52 & 36 & 0.32 \\
\hline $\begin{array}{l}\text { Bandarban } \\
\text { Sadar }\end{array}$ & 52794.83 & 3590.75 & 82 & 1.09 \\
\hline Total & $3,28,044.94$ & $16,477.95$ & 342 & 5.02 \\
\hline
\end{tabular}

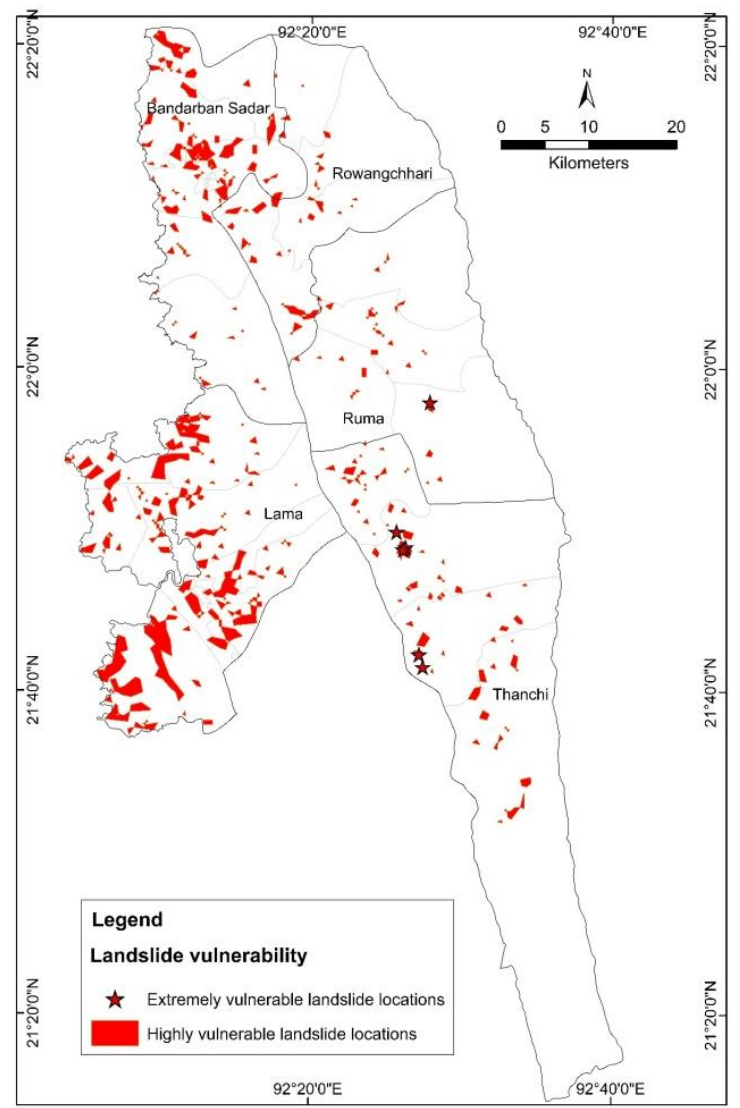

Figure 7: Landslides Vulnerability Locations in Bandarban District

Source: Geospatial model result, 2018
The results show that a total of 342 locations were found in Bandarban District as highly vulnerable to landslides (Table 3, Figure 7). The areal extent of the area is 16,477 hectares which are about 5.02 percent of the total area. In the vulnerability scale, the result shows that Lama Upazila is situated in the 1st position and Bandarban Sadar Upazila situated in the second position, then Thanchi, Rowanchhari, and Ruma (Table 3, Figure 7).

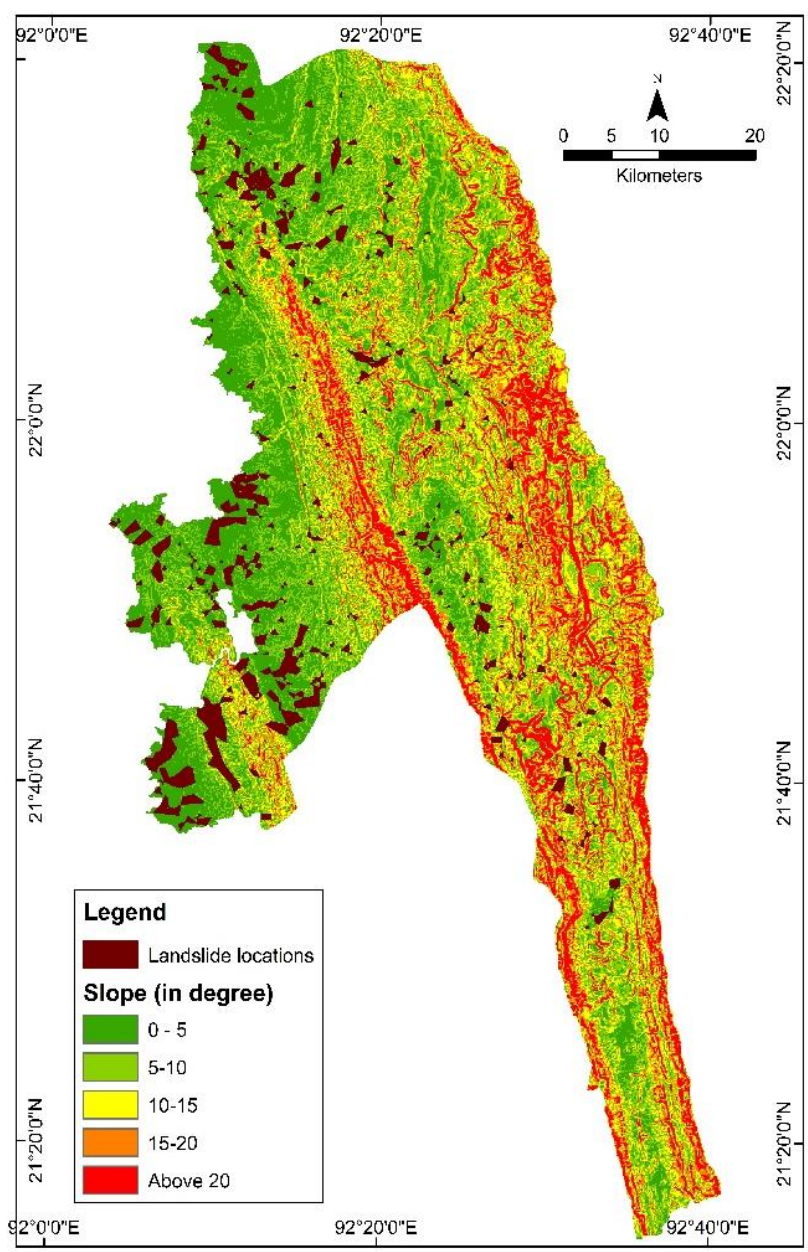

Figure 8: Landslides and Slope Relationship 


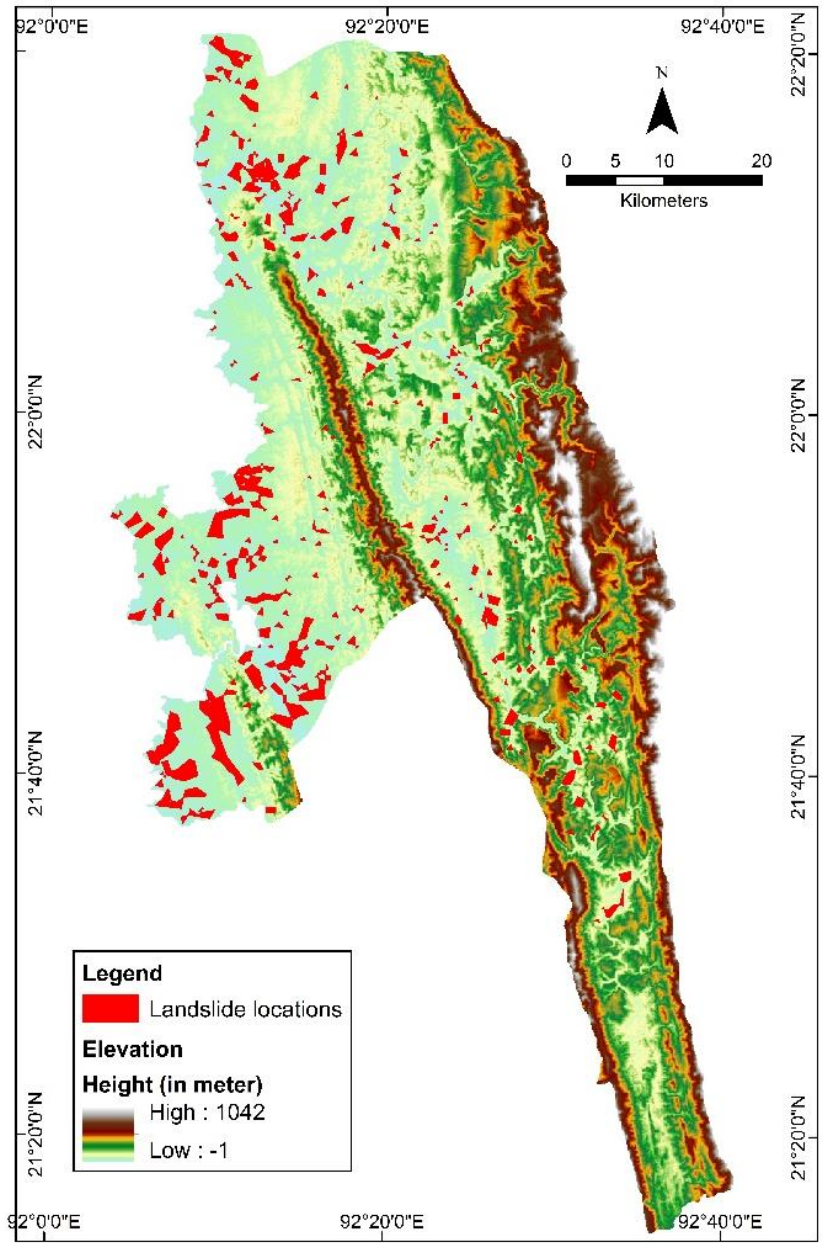

Figure 9: Landslides and Elevation Relationship

Table 4: Slope of the Landslides

\begin{tabular}{|l|l|}
\hline Slope (in degree) & Percentage of landslides \\
\hline $0-5$ & 65.57 \\
\hline $5-10$ & 25.20 \\
\hline $10-15$ & 6.55 \\
\hline $15-20$ & 1.90 \\
\hline 20 above & 0.79 \\
\hline \multicolumn{2}{|c|}{ Source: Data simulation from landslide and SRTM DEM }
\end{tabular}

\section{Relationship between landslides and}

slope: Landslides are related to the slope of the area. Model results show that about 66 percent of the landslides would occur in the slope about 5 degrees and about 25 percent of the landslides would occur in a slope between 5 and 10 degree (Table 4). Hence, about 91 percent of the landslides would occur within a 10-degree slope. And rest 9 percent of the landslides would occur above 10-degree slopes (Table 4 and Figure 8). Model shows that there is a strong negative correlation regression between landslides and slopes in degrees, where $\mathrm{r}=-0.81$.
Relationship between landslides and elevation: The elevation is the important factor related to the landslides vulnerability. The landslide probability model shows that about 65 percent of the landslides would occur within 50-meter elevation and about 27 percent of the landslides would occur between 50 to 100 meters elevation (Table 5 and Figure 9). Hence, about 92 percent of the landslides would occur in height about 100 meters. Data shows that there is a strong negative correlation regression between landslides and elevation, where $r=-0.83$.

Table 5: Elevation of the Landslides

\begin{tabular}{|l|l|}
\hline Elevation (in meter) & Percentage of Landslide Locations \\
\hline 50 & 64.75 \\
\hline 100 & 27.11 \\
\hline 150 & 5.67 \\
\hline 200 & 2.12 \\
\hline Above 200 & 0.35 \\
\hline \multicolumn{2}{|c|}{ Source: Data simulation from landslide and SRTM DEM }
\end{tabular}

Table 6: Geology of the Landslides

\begin{tabular}{|l|l|}
\hline Types of Geology & $\begin{array}{l}\text { Percentage of } \\
\text { Landslide Locations }\end{array}$ \\
\hline Valley Alluvium and Coluvium & 0.16 \\
\hline Dhighi Dupi Tilla Formation & 25.72 \\
\hline Girujan Clay & 6.85 \\
\hline Tipam Sandstone & 28.67 \\
\hline Boka Bil & 30.19 \\
\hline Bhuban Formation & 8.41 \\
\hline \multicolumn{2}{|c|}{ Source: Data simulation from landslide and geology }
\end{tabular}

Relationship between landslides and geological properties: The geological condition is a very important factor regarding landslides vulnerability. The present landslide model shows that about 30.19 percent of the landslides would occur at Boka Bil geology and the second probable condition would occur at Tipam Sandstone geology (28.67 percent) (Table 6 and Figure 10). Thirdly, about 25.72 percent of the landslides would occur at Dhighi Dupi Tilla Formation geology and the rest about 15 percent landslides would occur at Bhuban Formation, Girujan Clay and Valley Alluvium and Coluvium geology (Table 6 and Figure 10). There is a strong positive correlation regression between landslides and geological compactness, where $r=0.65$. 


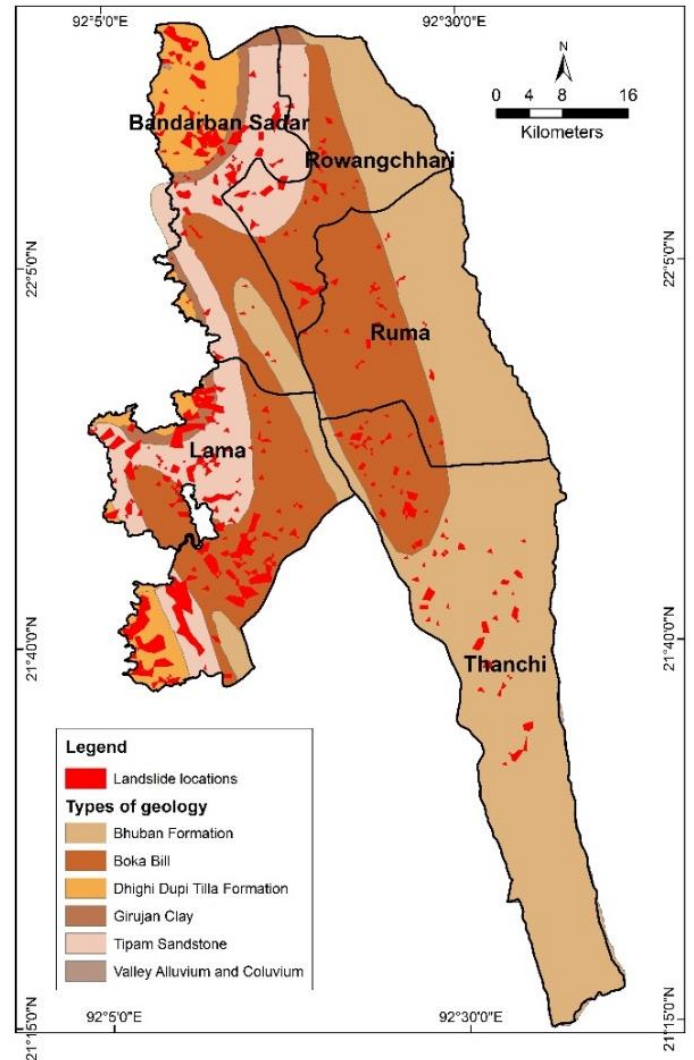

Figure 10: Landslides and Geology Relationship

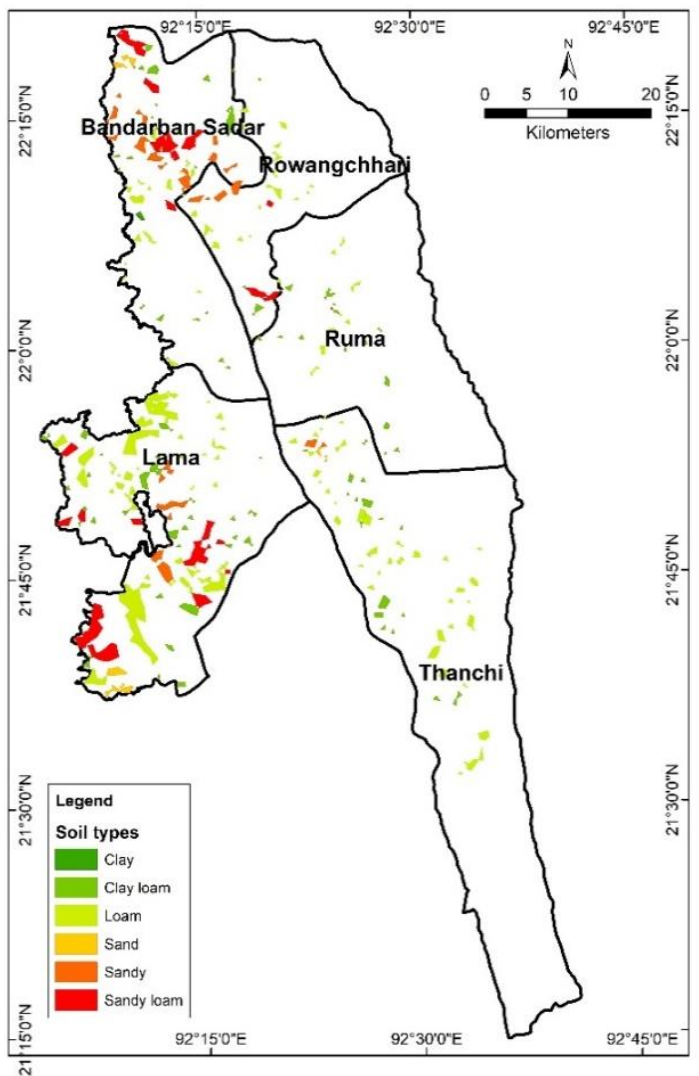

Figure 11: Landslides and Soil Types Relationship
Relationship between landslides and soil types: Among the landslides, the triggering factors, soil types are very important, which was established in the landslide model. The model result shows that about 25.12 percent of the landslides would occur in the sandy loam soil (Table 7, Figure 11); 15.56 percent would occur in sand and sandy soil; 43.28 percent would occur in loam soil, which is mixed soil of clay silt and sand; and lastly, about 15.75 percent of the landslides would occur in the clay loam soil (Table 7, Figure 11). Model shows that the soil types individually responsible for 40 percent landslides, where $r=0.40$.

Table 7: Soil Types of Landslides

\begin{tabular}{|l|l|}
\hline Soil types & Percentage of Landslides \\
\hline Sandy loam & 25.12 \\
\hline Sand and sandy & 15.56 \\
\hline Loam & 43.28 \\
\hline Clay Loam & 15.75 \\
\hline Clay & 0.30 \\
\hline \multicolumn{2}{|c|}{ Source: Data simulation from landslide and soil }
\end{tabular}

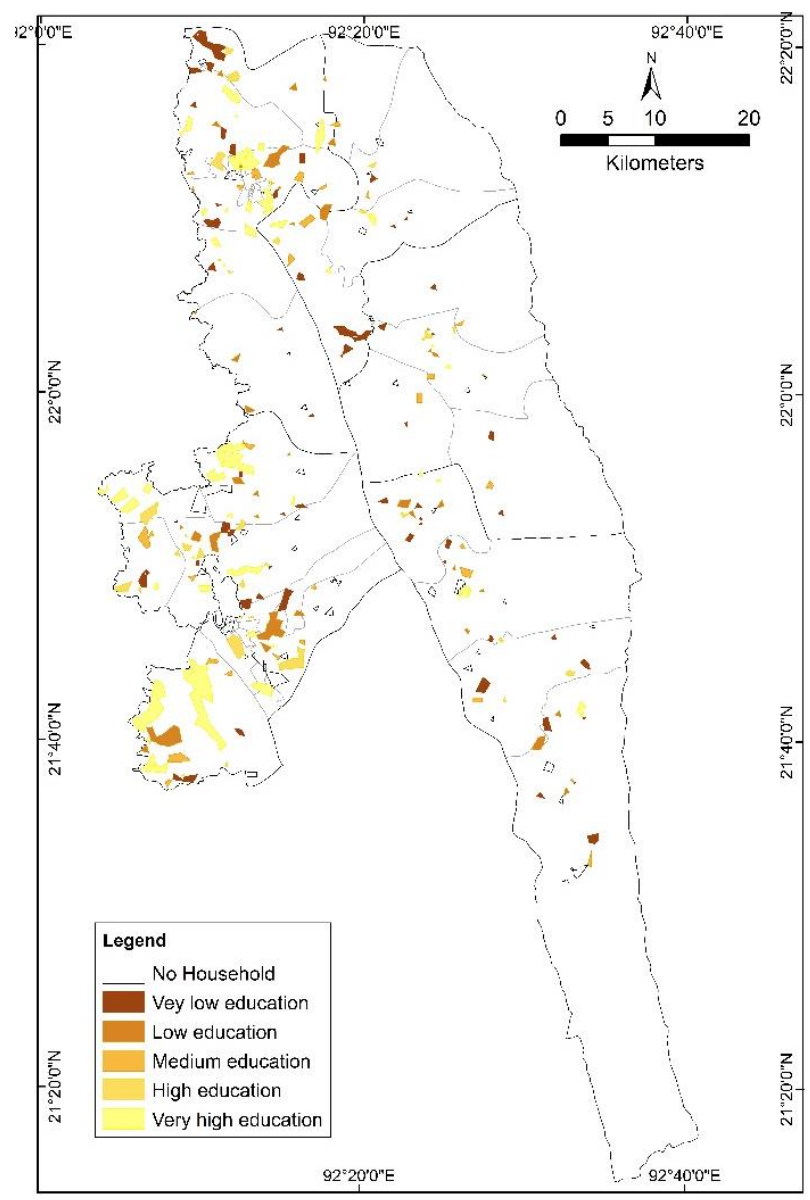

Figure 12: Landslides and Education Relationship 


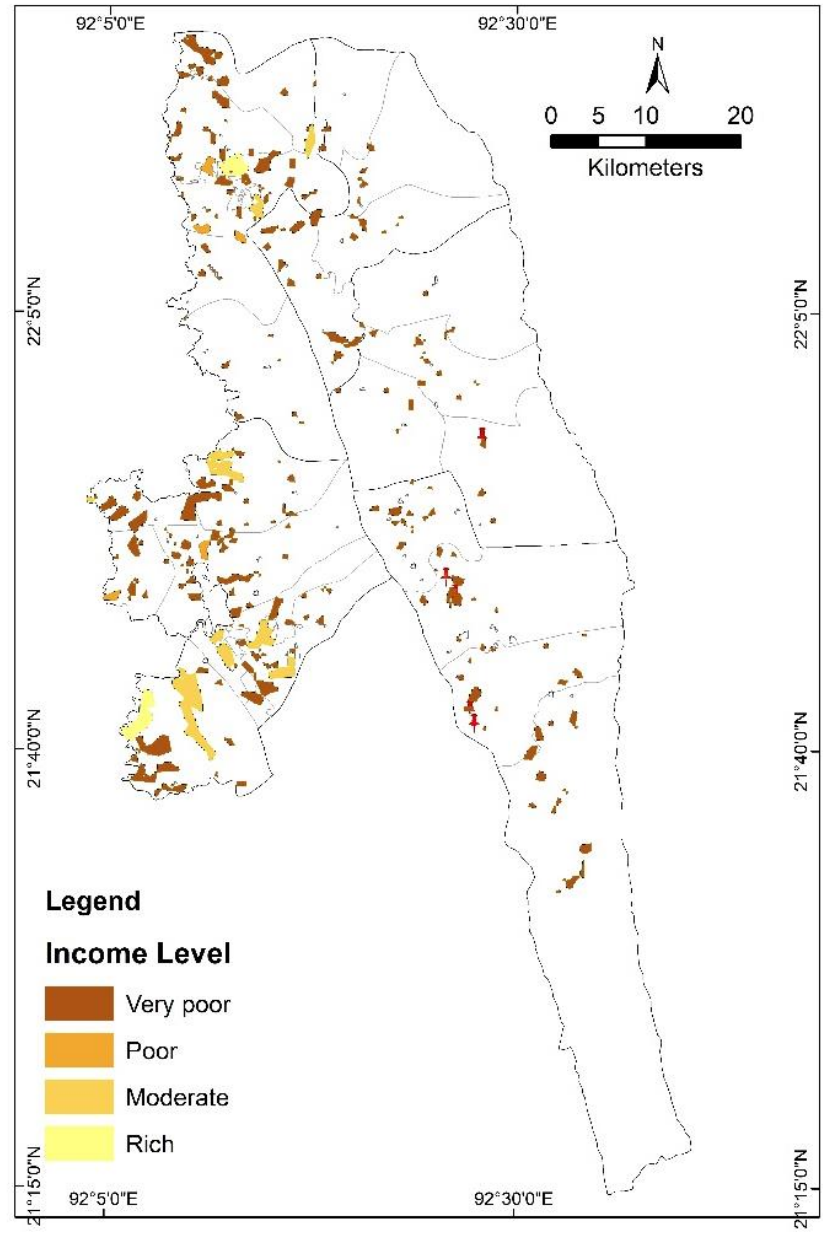

Figure 13: Landslides and Income Relationship

Table 8: Landslide and Income Relationship

\begin{tabular}{|l|l|l|}
\hline $\begin{array}{l}\text { Income } \\
\text { Level }\end{array}$ & $\begin{array}{l}\text { No. of Landslide } \\
\text { Parcels }\end{array}$ & $\begin{array}{l}\text { Percentage of } \\
\text { Landslides }\end{array}$ \\
\hline Very poor & 87 & 36.56 \\
\hline Poor & 112 & 37.05 \\
\hline Moderate & 43 & 24.37 \\
\hline Rich & 15 & 2.02 \\
\hline
\end{tabular}

Source: Data simulation from landslide and income of households

Relationship between income level and landslides: Model shows that 36.56 percent of inhabitants are very poor at the landslide area and 37.05 percent are poor; 24.37 percent were found moderate and only 2.02 percent inhabitants are rich at that area (Figure 13 and Table 8). There is a strong negative correlation regression between income and landslide, where $r=$ 0.92 .

Relationship between education level and landslides: Model shows that $15.41 \%$ of landslides areas inhabitants have no education (Table 9, Figure 13). On the other hand $17.22 \%$ landslides area was found where education level is $1-5$ and $11.78 \%$ has found where education level is 6-10; $9.37 \%$ area has $11-15$ education level; $9.67 \%$ area has $16-20$ education level; $14.20 \%$ has $21+$ education level and $22.36 \%$ area has education value null (Figure 13, Table 9). Education is negatively correlated with landslides. There is about 52 percent landslides story involved with education, where correlation regression, $r=-0.52$.

Table 9: Education of the Landslides Area

\begin{tabular}{|l|l|}
\hline Education of the Landslide Area & Percentage \\
\hline No education & 15.41 \\
\hline Very low educated & 17.22 \\
\hline Low educated & 11.78 \\
\hline Moderately educated & 9.37 \\
\hline High educated & 9.67 \\
\hline Very high educated & 14.20 \\
\hline No household & 22.36 \\
\hline \multicolumn{2}{|l|}{ Source Data simulation from landslide and household education }
\end{tabular}

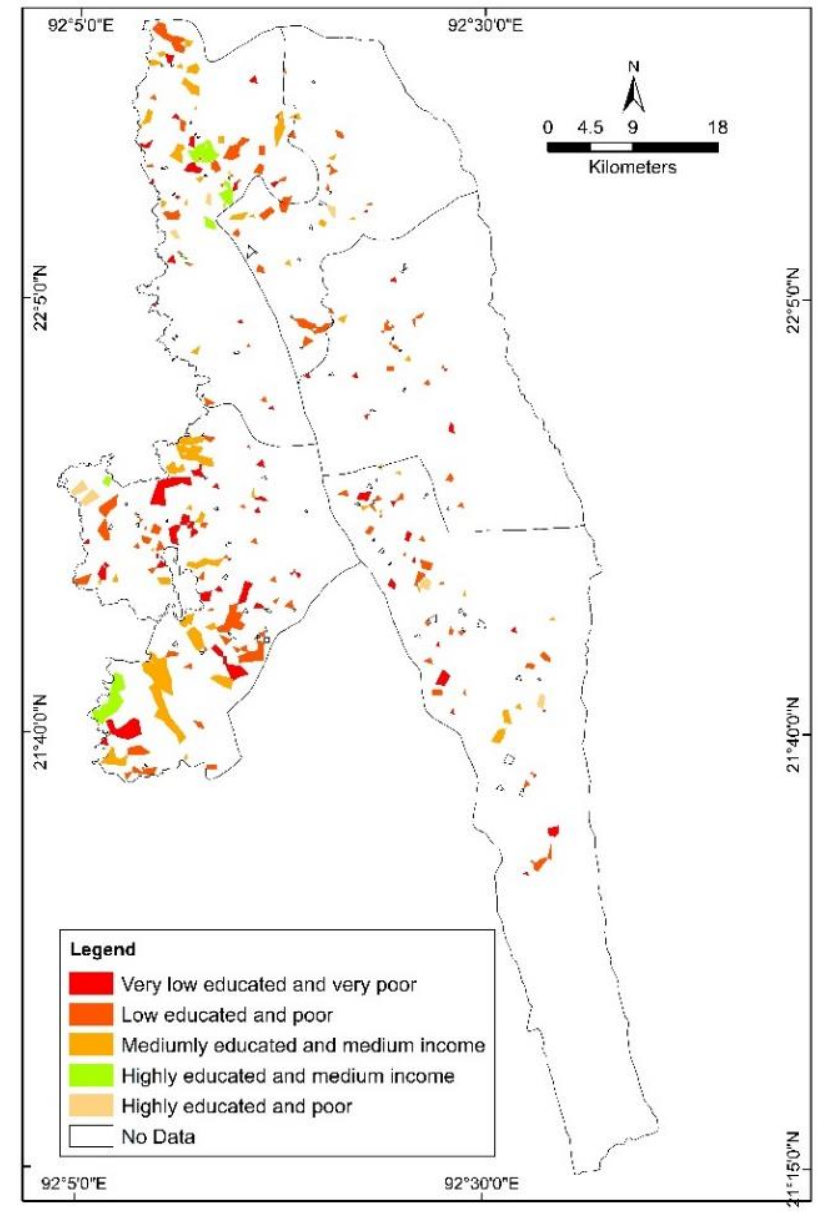

Figure 14: Landslide and Education-Income Relationship 
Table 10: Education and Income of the Landslides Area

\begin{tabular}{|l|l|l|}
\hline Education and Income Status & $\begin{array}{l}\text { No. of } \\
\text { Parcels }\end{array}$ & $\begin{array}{l}\text { Percentage of } \\
\text { Area }\end{array}$ \\
\hline $\begin{array}{l}\text { Very Low Educated and Very } \\
\text { Poor }\end{array}$ & 64 & 17.80 \\
\hline Low Educated and Poor & 110 & 27.27 \\
\hline $\begin{array}{l}\text { Moderately Educated and } \\
\text { Medium Income }\end{array}$ & 116 & 43.76 \\
\hline $\begin{array}{l}\text { Highly Educated and Medium } \\
\text { Income }\end{array}$ & 8 & 7.90 \\
\hline Highly Educated and Poor & 7 & 3.27 \\
\hline
\end{tabular}

Source: Data simulation from landslide and education and income of the household

The model results show that 17.8 percent of the landslides area people have very low education and very poor; 27.27 percent of the landslides area people have low education and poor and 43.76 percent of the landslides area people have medium education and medium-income (Table 10, Figure 14).

\section{CONCLUSION}

Modeling landslides vulnerability is an important tool in facilitating the planners to manage landslides and support sustainable development in a particular area. The landslide model predicts 384 landslide vulnerable locations in Bandarban District. According to model results, 6 locations are extremely vulnerable and 342 locations were found as highly vulnerable. The model shows that about 3 percent area of Lama Upazila and 1.1 percent area of Bandarban Sadar Upazila are vulnerable to landslides. It is evident that though low slope (slope up to 10 degrees) and low elevations (up to 100 meters) are suitable for inhabitant to live but are most vulnerable to landslides because of human intervention. Geological formation Boka Bil (30.19\%), Tipam Sandstone (28.67\%) and Dhigi Dupi Tilla formation (25.72\%) are involved with landslide vulnerability. Soil types are another important variable to landslide vulnerability. The model shows that loam soil $(43.28 \%)$, sandy loam $(25.12 \%)$ and sand and sandy soil $(15.56 \%)$ were involved with landslide vulnerability. Education and landslides are strongly related, no education triggered about 15.4 percent of landslides, very low education triggered about 17 percent landslides and low education triggered about 12 percent of landslides. Similarly, the model results show that poorness of the peoples are also the causal factor for land slide. Model illustrates that landslide occurs for 36.6 percent, 37 percent and 24 percent areas inhabited by very poor, poor and people with moderate income respectively. There is a strong negative correlation regression between landslides and slopes in degrees, where correlation regression, $r=-0.81$. Similarly, there is a strong negative correlation regression between landslides and elevation, where correlation regression, $\mathrm{r}=-0.83$. There is a positive correlation regression between landslides and geological compactness, where correlation regression, $r=0.65$. Similarly, 40 percent of the landslides are related to soil types. Besides physical factors, inhabitant's income and education similarly correlated with landslides. 92 percent of landslides correlated with income, there is a strong negative correlation regression between income and landslides $(\mathrm{r}=-0.92)$. Education is also negatively correlated with landslides. Hence the correlation regression, $r=-0.52$. Furthermore, less educated and low-income people are living under the poverty line. It has appeared that there is a strong relationship between poverty and landslide vulnerability. The poor people are utmost depended on the land cover to meet their necessary need. Therefore, the poorer intervened the land to their surroundings excessively and induces natural disaster such as landslides. Under the circumstances, attention should be given to the poor people to uplift their livelihood.

ACKNOWLEDGEMENT: Helen Keller International (HKI) is thankfully acknowledged to provide fund for the study and sign an MoU with GIS Lab, Department Geography and Environment, University of Dhaka. The author also acknowledges Mr. Hindole, Deputy Director of HKI and Mr. Anamik Ani Khan, GIS Officer of HKI for their kind supports.

\section{REFERENCES}

Abdulwahid, W.M., Pradhan, B. (2016). Landslide vulnerability and risk assessment for multihazard scenarios using airborne laser scanning data (LiDAR). Landslides. doi: 10.1007/s10346-016-0744-0.

Agliardi, F., Crosta, G.B., Frattini, P. (2009). Integrating rockfall risk assessment and countermeasure design by 3D modeling techniques. Nat Hazard Earth Syst Sci., 9:1059-1073.

Ayalew, L., Yamagishi. H., Marui, H., Kanno, T. (2005). Landslides in Sado Island of Japan: Part II. GIS-based susceptibility mapping with comparisons of results from two methods and verifications. Eng Geol., 81:432-445. 
BBS. (2011). Bangladesh Disaster-related Statistics 2015: Climate Change and Natural Disaster Perspectives, Bangladesh Bureau of Statistics, Government of the People's Republic of Bangladesh.

Corominas, J., Copons, R., Moya, J., Vilaplana, J,M, Altimir, J, Amigo, J. (2005). Quantitative assessment of the residual risk in a rockfall protected area. Landslides, 2:343-357. GEOMATICS, NATURAL HAZARDS AND RISK 1031.

Crosta, G.B.; Frattini, P. (2008). Rainfall-induced landslides and debris flows. Hydrol. Process, 22: 473477.

Cruden, D.M.,Varnes, D.J.,(1996). Landslide Types and Processes, Transportation Research Board, U.S. National Academy of Sciences, Special Report, 247: 36-75.

Devkota, K.C., Regmi, A.D., Pourghasemi. H.R., Yoshida. K., Pradhan, B. (2013). Landslide susceptibility mapping using certainty factor, index of entropy and logistic regression models in GIS and their comparison at Mugling- Narayanghat road section in Nepal Himalaya. Nat Hazards, 65:135-165. doi: 10.1007/s11069-012-0347-6

Dhakal, A.S., Sidle, R.C. (2003). Long-term modelling of landslides for different forest management practices. Earth Surf. Process. Landf, 28: 853-868.

Dietrich, W., Montgomery, D. (1988). A Digital Terrain Model for Mapping Shallow Landslide Potential (SHALSTAB); University of California: Berkeley, CA, USA.

El-Emam, M.M., Bathurst, R.J. (2007). Influence of reinforcement parameters on the seismic response of reduced-scale reinforced soil retaining walls. Geotext. Geomembr, 25: 33-49.

Fell, R., Corominas, J., Bonnard, C., Cascini, L., Leroi, E., Savage, W.Z. (2008). Guidelines for landslide susceptibility, hazard and risk zoning for land use planning. Eng Geol., 102:85-98.

Ferlisi, S., Cascini, L., Corominas, J., Matano, F. (2012). Rockfall risk assessment to persons travelling in vehicles along a road: the case study of the Amalfi coastal road (southern Italy). Nat Hazard, 62:691-721.

Formetta, G., Rago, V., Capparelli, G., Rigon, R., Muto, F., Versace, P. (2014). Integrated physically based System for Modeling Landslide Susceptibility. Procedia Earth Planet. Sci., 9: 74-82.

Glade, T. (2003). Vulnerability assessment in landslide risk analysis. Die Erde., 134:121-138.
Hildenbrand, A., Pirre-Yves, G., Vicente, S., Pirre, L. (2003). Evidence for a persistent uplifting of La Palma (Canary Islands), inferred from morphological and radiometric data. Earth and Planetary Science Letters. $210(0)$, p. 277-289.

Jeong, S., Lee, K., Kim, J., Kim, Y. (2017). Analysis of rainfall-induced landslide on unsaturated soil slopes. Sustainability, 9: 1280.

Kavzoglu, T., Sahin, E.K., Colkesen, I. (2014). Landslide susceptibility mapping using GIS-based multi-criteria decision analysis, support vector machines, and logistic regression. Landslides. 11:425439. doi: 10.1007/s10346-013-0391-7.

Keller, E. A., and Blodgett, R. H. (2004). Natural Hazards: Earth's Processes as Hazards, Disasters, and Catastrophes by Keller, Edward A.; Blodgett, Robert H. published by Prentice Hall Paperback.

Korup, O. (2004). Landslide-induced river channel avulsions in mountain catchments of southwest New Zealand. Geomorphology, 63: $57-80$.

Korup, O. (2005). Geomorphic imprint of landslides on alpine river systems, southwest New Zealand. Earth Surface Processes and Landforms, 0: 83 -800.

Korup, O. (2006). Effects of deep-seated bedrock landslides on hillslope morph- ology, Southern Alps, New Zealand. Journal of Geophysical Research, 11, F01018, doi:10.1029/2004JF000242.

Lee, S., Hong, S.-M., Jung, H.-S. (2017). A support vector machine for landslide susceptibility mapping in Gangwon province, Korea. Sustainability, 9, 48.

Mavrouli, O. and Corominas, J. (2010). Vulnerability of simple reinforced concrete buildings to damage by rockfalls. Landslides, 7:169-180.

Mitchell, N. C., Masson, D. G., Watts, A. B., Gee, M. J.R., Urgeles, R. (2002). The morphology of the submarine flanks of volcanic ocean islands. A comparative study of the Canary and Hawaiian hotspot islands. Journal of Volcanology and Geothermal Research, 115:83-107.

Pellicani, R., Frattini, P., Spilotro, G. (2014). Landslide susceptibility assessment in Apulian Southern Apennine: heuristic vs. statistical methods. Environ Earth Sci., 72:1097-1108. doi: 10.1007/s12665-0133026-3.

Pellicani, R., Van-Westen, C.J., Spilotro, G. (2014). Assessing landslide exposure in areas with limited landslide information. Landslides, 11:463-480. doi: 10.1007/s10346-013-0386-4. 
Pham, B.T., Pradhan, B., Bui, D.T., Prakash, I., Dholakia, M.B. (2016). A comparative study of different machine learning methods for landslide susceptibility assessment: a case study of Uttarakhand area (India). Environ Model Soft, 84:240-250.

Safaei, M., Omar, H., Huat, B., Yousof, Z.B.M., Ghiasi, V. (2011). Deterministic rainfall induced landslide approaches, advantage and limitation. Electron. J. Geotech. Eng., 16: 1619-1650.

Shahabi, H., Khezri, S., Ahmad, B., Hashim, M. (2014). Landslide susceptibility mapping at central Zab basin, Iran: a comparison between analytical hierarchy process, frequency ratio and logistic regression models. Catena, 115:55-70.

Simoni, S., Zanotti, F., Bertoldi, G., Rigon, R. (2008). Modelling the probability of occurrence of shallow landslides and channelized debris flows using GEOtopFS. Hydrol. Process, 22, 532-545.

Soeters, R., Van-Westen, C.J. (1996). Slope stability: recognition, analysis and zonation. In: Turner AK, Shuster RL, editors. Landslides: investigation and mitigation. Special Report 247. Washington (DC): Transportation Research Board - National Research Council; p. 129-177.
Sofiullah, M. (2018). Geospatial Research of Bandarban District of Chittagong Hill Tracts, Final Report. Report Submitted to Helen Keller International under a MoU between HKI and GIS Lab, Department of Geography and Environment, University of Dhaka.

Sofiullah, M., Khan, A.A. and Hossain, M. A. (2017). Spatiotemporal Variability of Rainfall in Bangladesh Using Thiessen Polygon and Spile Interpolation, Oriental Geographer, 58 (2):91-111.

Summerfield, M. (1991). Global geomorphology. England: Pearson Education Limited. P. 169.

Turner, A. and Schuster R. (1996). Landslides. Investigation and mitigation. Washington D.C.: National Academy Press. p. 53-67.

Uzielli, M., Nadim, F., Lacasse, S., Kaynia, A.M. (2008). A conceptual frame work for quantitative estimation of physiscal vulnerability to landslides. Eng Geol. 102:251-256. 1032 R. PELLICANI ET AL.

Van-Westen, C.J. (2000). The modelling of landslide hazard using GIS. Surv Geophys., 21:241-255.

Wang, X., Frattini, P., Crosta, G.B., Zhang, L., Agliardi. F., Lari, S., Yang, Z. (2014). Uncertainty assessment in quantitative rockfall risk assessment. Landslides, 11:711-722. 
Appendix Table 1: Tabular Information of ArcGIS Weighted Overlay Procedure






\begin{tabular}{|c|c|c|c|c|c|}
\hline \multirow{9}{*}{ Variable } & \multirow{9}{*}{ Number/Values } & \multicolumn{2}{|l|}{ Data Range } & \multirow{2}{*}{$\begin{array}{l}\text { Weighted } \\
\text { Overlay } \\
1 \text { to } 10 \text { scale } \\
\text { by } 1\end{array}$} & \multirow{9}{*}{$\begin{array}{l}\text { Influence } \\
(\mathbf{1 0 0 \%})\end{array}$} \\
\hline & & From & To & & \\
\hline & & 14389.32 & 19185.76 & 7 & \\
\hline & & 19185.76 & 23982.21 & 6 & \\
\hline & & 23982.21 & 28778.65 & 5 & \\
\hline & & 28778.65 & 33575.09 & 4 & \\
\hline & & 33575.09 & 38371.53 & 3 & \\
\hline & & 38371.53 & 43167.97 & 2 & \\
\hline & & 43167.97 & 47964.41 & 1 & \\
\hline \multirow{10}{*}{ Stream Line Euclidean Distance (meters) } & \multirow{10}{*}{0 to 42407} & 0 & 100 & 10 & \multirow{10}{*}{10} \\
\hline & & 100 & 200 & 9 & \\
\hline & & 200 & 300 & 8 & \\
\hline & & 300 & 400 & 7 & \\
\hline & & 400 & 500 & 6 & \\
\hline & & 500 & 600 & 5 & \\
\hline & & 600 & 700 & 4 & \\
\hline & & 700 & 800 & 3 & \\
\hline & & 800 & 900 & 2 & \\
\hline & & 900 & 42407.1 & 1 & \\
\hline \multirow{10}{*}{ Road Euclidean Distance (meters) } & \multirow{10}{*}{0 to 64279.11} & 0 & 3781.12 & 10 & \multirow{10}{*}{6} \\
\hline & & 3781.12 & 9326.77 & 9 & \\
\hline & & 9326.77 & 15376.57 & 8 & \\
\hline & & 15376.57 & 21174.29 & 7 & \\
\hline & & 21174.29 & 26972.02 & 6 & \\
\hline & & 26972.02 & 33021.82 & 5 & \\
\hline & & 33021.82 & 39071.62 & 4 & \\
\hline & & 39071.62 & 45373.49 & 3 & \\
\hline & & 45373.49 & 52935.74 & 2 & \\
\hline & & 52935.74 & 64279.11 & 1 & \\
\hline \multirow{10}{*}{$\begin{array}{l}\text { Monsoon rainfall standard deviation } \\
\text { (1964 to 2017) }\end{array}$} & \multirow{10}{*}{29.38 to 61.87} & 29.382914 & 32.631968 & 10 & \multirow{10}{*}{5} \\
\hline & & 32.631968 & 35.881023 & 9 & \\
\hline & & 35.881023 & 39.130077 & 8 & \\
\hline & & 39.130077 & 42.379132 & 7 & \\
\hline & & 42.379132 & 45.628186 & 6 & \\
\hline & & 45.628186 & 48.877241 & 5 & \\
\hline & & 48.877241 & 52.126295 & 4 & \\
\hline & & 52.126295 & 55.37535 & 3 & \\
\hline & & 55.37535 & 58.624404 & 2 & \\
\hline & & 58.624404 & 61.873459 & 1 & \\
\hline \multirow{12}{*}{ Land Use } & Building/House & & & 1 & \multirow{12}{*}{8} \\
\hline & Built Up Area & & & 1 & \\
\hline & Playground & & & 1 & \\
\hline & Stadium & & & 1 & \\
\hline & Sandy Char Land & & & 1 & \\
\hline & Beel & & & 1 & \\
\hline & Haor & & & 1 & \\
\hline & Lake & & & 1 & \\
\hline & \begin{tabular}{|l|} 
Pond \\
\end{tabular} & & & 1 & \\
\hline & \begin{tabular}{|l|} 
River \\
\end{tabular} & & & 1 & \\
\hline & Marsh Wetland & & & 1 & \\
\hline & Cultivation Land & & & 7 & \\
\hline
\end{tabular}




\begin{tabular}{|c|c|c|c|c|c|}
\hline \multirow{6}{*}{ Variable } & \multirow[b]{2}{*}{ Number/Values } & \multicolumn{2}{|c|}{ Data Range } & \multirow{2}{*}{$\begin{array}{l}\text { Weighted } \\
\text { Overlay } \\
1 \text { to } 10 \text { scale } \\
\text { by } 1\end{array}$} & \multirow{6}{*}{$\begin{array}{l}\text { Influence } \\
(100 \%)\end{array}$} \\
\hline & & From & To & & \\
\hline & Uncultivation Land & & & 8 & \\
\hline & Vegetation & & & 9 & \\
\hline & Forest & & & 10 & \\
\hline & Garden & & & 1 & \\
\hline \multirow{10}{*}{ Household density } & \multirow{10}{*}{0 to 275} & 0 & 27.5 & 1 & \multirow{10}{*}{7} \\
\hline & & 27.5 & 55 & 2 & \\
\hline & & 55 & 82.5 & 3 & \\
\hline & & 82.5 & 110 & 4 & \\
\hline & & 110 & 137.5 & 5 & \\
\hline & & 137.5 & 165 & 6 & \\
\hline & & 165 & 192.5 & 7 & \\
\hline & & 192.5 & 220 & 8 & \\
\hline & & 220 & 247.5 & 9 & \\
\hline & & 247.5 & 275 & 10 & \\
\hline \multirow{6}{*}{ Education } & No education & & & 10 & \multirow{6}{*}{5} \\
\hline & Very low education & & & 9 & \\
\hline & Low education & & & 8 & \\
\hline & Medium education & & & 7 & \\
\hline & High education & & & 6 & \\
\hline & Very high education & & & 5 & \\
\hline \multirow{4}{*}{ Income } & Very Poor & & & 10 & \multirow{4}{*}{4} \\
\hline & Poor & & & 9 & \\
\hline & Medium & & & 8 & \\
\hline & Rich & & & 7 & \\
\hline
\end{tabular}

